\title{
Traumatic Brain Injury and Blood-Brain Barrier (BBB): Underlying Pathophysiological Mechanisms and the Influence of Cigarette Smoking as a Premorbid Condition
}

\author{
Farzane Sivandzade ${ }^{1}\left(\mathbb{D}\right.$, Faleh Alqahtani ${ }^{2}\left(\mathbb{D}\right.$ and Luca Cucullo ${ }^{1,3, *(\mathbb{C}}$ \\ 1 Department of Pharmaceutical Sciences, Texas Tech University Health Sciences Center, Amarillo, TX 79106, \\ USA; farzane.sivandzade@ttuhsc.edu \\ 2 Department of Pharmacology and Toxicology, College of Pharmacy, King Saud University, Riyadh 11451, \\ Saudi Arabia; afaleh@KSU.EDU.SA \\ 3 Center for Blood-Brain Barrier Research, Texas Tech University Health Sciences Center, Amarillo, \\ TX 79106, USA \\ * Correspondence: luca.cucullo@ttuhsc.edu; Tel.: +806-414-9237
}

Received: 1 April 2020; Accepted: 12 April 2020; Published: 14 April 2020

\begin{abstract}
Traumatic brain injury (TBI) is among the most pressing global health issues and prevalent causes of cerebrovascular and neurological disorders all over the world. In addition to the brain injury, TBI may also alter the systemic immune response. Thus, TBI patients become vulnerable to infections, have worse neurological outcomes, and exhibit a higher rate of mortality and morbidity. It is well established that brain injury leads to impairments of the blood-brain barrier (BBB) integrity and function, contributing to the loss of neural tissue and affecting the response to neuroprotective drugs. Thus, stabilization/protection of the BBB after TBI could be a promising strategy to limit neuronal inflammation, secondary brain damage, and acute neurodegeneration. Herein, we present a review highlighting the significant post-traumatic effects of TBI on the cerebrovascular system. These include the loss of BBB integrity and selective permeability, impact on BBB transport mechanisms, post-traumatic cerebral edema formation, and significant pathophysiological factors that may further exacerbate post-traumatic BBB dysfunctions. Furthermore, we discuss the post-traumatic impacts of chronic smoking, which has been recently shown to act as a premorbid condition that impairs post-TBI recovery. Indeed, understanding the underlying molecular mechanisms associated with TBI damage is essential to better understand the pathogenesis and progression of post-traumatic secondary brain injury and the development of targeted treatments to improve outcomes and speed up the recovery process. Therapies aimed at restoring/protecting the BBB may reduce the post-traumatic burden of TBI by minimizing the impairment of brain homeostasis and help to restore an optimal microenvironment to support neuronal repair.
\end{abstract}

Keywords: traumatic brain injury; blood-brain barrier; oxidative stress; cigarette smoke; neuroinflammation; excitotoxicity

\section{Introduction}

Traumatic brain injury (TBI) is defined as an insult to the brain caused by a direct or indirect external mechanical force. TBI has long been among the foremost leading causes of death and disability in the United States, thus becoming a serious public health concern in modern society [1-7]. According to the Centers for Disease Control and Prevention (CDC), every year, about 2.5 million people in the U.S. seek emergency care for TBI secondary to motor vehicle accidents, falls, assaults, 
sports-related events, and other mechanisms. In addition, every year, more than 5.3 million Americans live with a lifelong disability caused by TBI [8-10]. In those that survive, the effects of TBI can cause emotional, physiological, cognitive, motor, and behavioral impairments ranging from mild to severe [5,11-14]. Mild traumatic brain injury (mTBI) accounts for over $80 \%$ of head injuries [1]. mTBI typically results in transient symptoms, including sensitivity to light and sound, headache, vision impairment, difficulties with cognition, and balance. The severity of TBI is classified into three degrees (depending on the length of unconsciousness following the head injuries), including mild TBI (loss of consciousness $\approx 15 \mathrm{~s}$ ), moderate TBI (loss of consciousness of several minutes), and severe TBI (loss of consciousness $\geq 1 \mathrm{~h}$ ) [15]. Approximately $20-40 \%$ of patients die after a severe TBI due to brain injury or secondary complications, and those that survive often have reduced life expectancies, chronic neurological disabilities, pituitary dysfunction, and cognitive and psychological disorders, including depression and aggression [1,15-18]. In fact, after a moderate or severe TBI, most patients require hospitalization for medical management. During the post-hospital recovery phase, they often deal with reduced cognitive abilities, anxiety and depression disorder, and impaired balance and coordination. Needless to say that these post-traumatic effects burden the patient with a higher risk of re-hospitalization, as well as an additional economic burden for the individual and his/her family and reduced quality of life $[17,18]$. Researchers in the field have been focusing on several aspects of TBI, including the physical characteristics of the trauma and the lapse time between trauma and the initial onset of neuropathologies [19]. The development of TBI is divided into two general stages: primary (immediate) injury and secondary (delayed) injury [2,20]. The primary trauma encompasses all acute pathological changes, such as shearing injuries, contusions, and hematomas [2,21]. Secondary changes, including the formation of cerebral edema, oxidative stress (OS), inflammation, excitotoxicity, imbalanced calcium homeostasis, enhanced vascular permeability, and blood-brain barrier (BBB) impairment often occur following vascular and parenchymal damage in the brain. Secondary injury events can significantly exacerbate post-traumatic brain injury and worsen clinical outcomes [22-24] (see also Figure 1). 


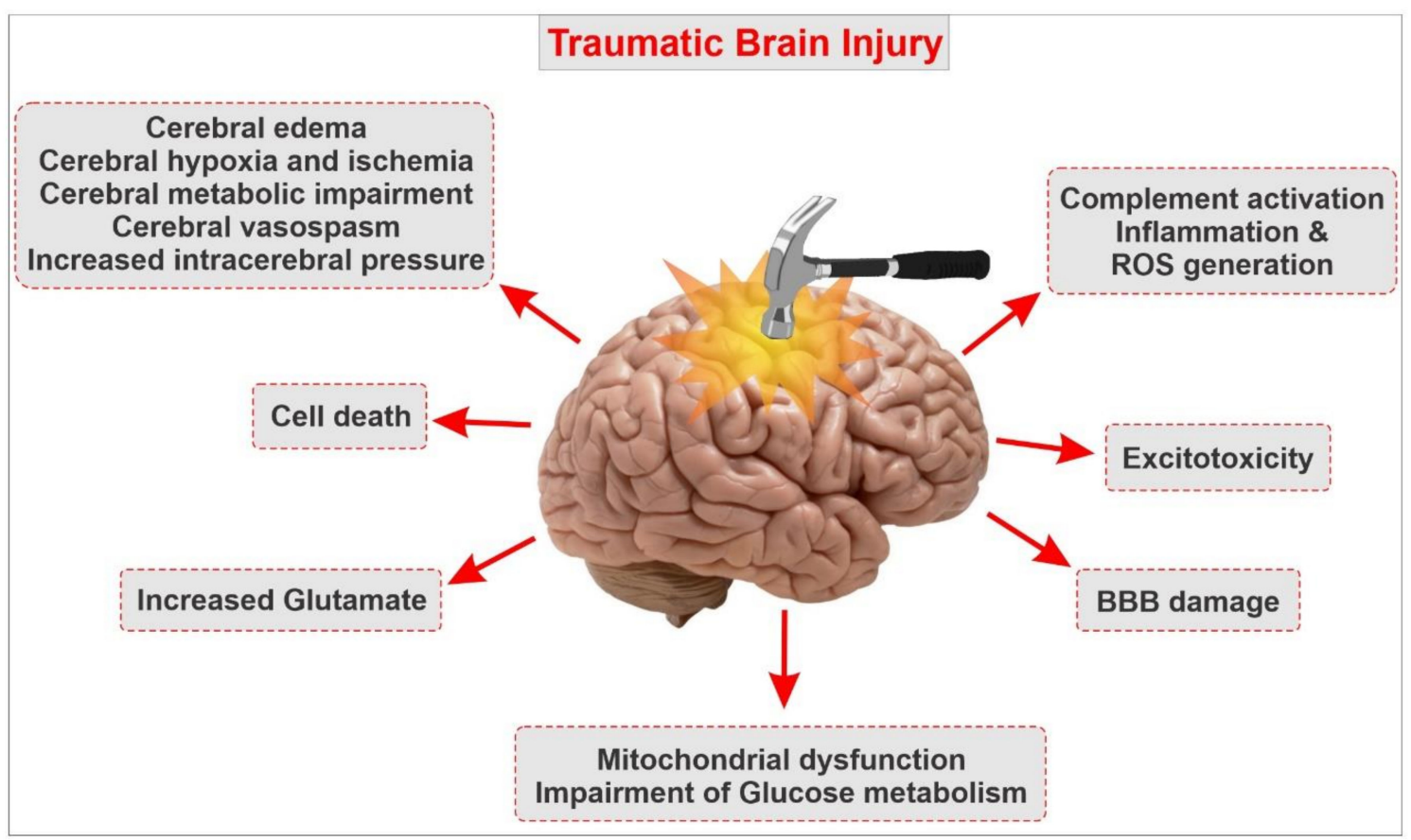

Figure 1. Simple schematic outlining the pathophysiological responses following traumatic brain injury and the complex outburst of secondary impairments. Note that secondary injury processes of traumatic brain injury (TBI) include blood-brain barrier (BBB) disruption, neuroinflammation, excitotoxicity, metabolic impairments, apoptosis, oxidative stress, ischemia, and others. Associated with BBB impairment, microglial and astrocyte activation, leukocyte infiltration, and upregulation of pro-inflammatory cytokines are characteristic of the neuroinflammatory response of TBI.

Concerning the involvement of the $\mathrm{BBB}$, substantial pieces of evidence are suggesting that TBI impairs the BBB, and BBB damage is implicated in the loss of neurons, altered brain function, and possibly the response to therapy. Post-traumatic dysfunction of the BBB is one of the significant factors determining the progression of injury and affecting the time course and the extent of neuronal repair [25]. This review covers the pathogenesis of TBI and encompasses the major pathophysiological factors that promote post-traumatic dysfunction of the BBB and its involvement in the onset of post-TBI neuropathologies. We also provide a brief review of the current treatment used to alleviate the burden of TBI.

\section{The Blood-Brain Barrier Interface}

The BBB is a dynamic functional interface between the blood and the central nervous system (CNS), which allows nutrients, essential amino acids, ions, etc. to transport between the peripheral circulation and the brain. At the same time, it inhibits many pathogens and toxic compounds from entering the brain [26-29]. The primary functions of the BBB are to maintain the homeostasis in the brain and protect the brain from potentially endogenous and xenobiotics, leading to optimal neuronal activity [3,15]. Generally, the BBB is formed by the brain endothelial cells [30]. The junctions between endothelial cells are tightly connected through the adherens junction (AJ) proteins such as cadherins and tight junctional proteins such as occludin and claudins [31]. Besides, astrocytes, microglia, and pericytes are also critical for the normal function of the BBB and the phenotype of brain endothelial cells so that they contribute to the formation and maintenance, selectivity, and specificity of the BBB [19,32]. Glial and endothelial cells functionally interact with each other in a paracrine manner contributing to the integrity of the BBB [30]. The efflux transporters present on the endothelial cells, such as the P-glycoprotein (Pgp), multidrug-resistant protein (MRP), and breast-cancer-resistance protein (BCRP) support the selective function of the BBB by actively moving various lipophilic drugs 
out of brain endothelial cells. Together, the physical and metabolic barrier of the BBB plays a crucial role in maintaining brain homeostasis.

\section{Chronic Smoking: A Major Comorbid Factor for BBB Dysfunction and Significant Neurological Disorders}

Tobacco smoke (TS) is a diverse mixture of over 4700 toxic compounds, including carcinogens and mutagenic chemicals, as well as stable and unstable free radicals and reactive oxygen species (ROS). Chronic smoking is one of the leading preventable causes of morbidity and mortality that affects the function of almost every organ of the body, giving rise to a range of illnesses that reduce life expectancy in smokers $[33,34]$. TS is responsible for approximately 6 million deaths per year in the world and more than 480,000 deaths each year just in the United States (US). Smoking has been strongly associated with enhanced the risk of stroke and other cerebrovascular and neurological disorders such as Alzheimer's, multiple sclerosis, and vascular dementia [35]. The mechanisms through which TS promotes the onset and progression of various cerebrovascular and neurodegenerative diseases are multifaceted. They include OS, BBB dysfunction, inflammation, alteration of cellular redox metabolic activities, and the activation of immune responses [36,37]. There is numerous evidence suggesting the pivotal role of oxidative stress in endothelial dysfunction and following BBB damage in the cerebrovascular level [38]. The exposure of tobacco smoke even at non-toxic concentration induces a robust inflammatory response in cells that influences the cerebrovascular endothelium and circulating immune cells [39]. The inflammatory response and reduced cerebral blood flow, which are both are common in chronic smokers, result in exaggerated the damage of BBB, suggesting its contribution toward cerebrovascular disease and ischemic stroke [40]. It has been claimed by various studies that smoking increases the risk of neuroinflammatory disorders, i.e., Alzheimer's disease, and multiple sclerosis [40]. A previous study showed that chronic prenatal exposure to nicotine could induce the unusual discharge of neurochemicals, followed by several pathological consequences in children. The study also demonstrated that nicotine causes an abnormal differentiation of neuronal cells, decreases synaptic activity, and promotes apoptosis, thus leading to abnormal brain development. Tobacco smoke may provoke the expression of several adhesion molecules and the release of tumor necrosis factor-alpha (TNF- $\alpha$ ), interleukin-6 (IL-6), and matrix metalloproteinase-2 (MMP-2). Altogether, these are essential in the regulation of leukocytes movement across the endothelium into adjacent tissue and contribute toward perivascular inflammation. Altered BBB integrity and increased atherogenesis may eventually lead to ischemic insult. The pro-inflammatory role of TS might be the result of its impact on the transcription of genes that are involved in the pathogenesis of atherosclerosis and modulate the inflammatory reaction at the BBB level. TS can cause the significant upregulation of various transcription factors, which can play an essential role in the gene expression of cytokines, chemokines, and different adhesion molecules, i.e., E-selectin and Intercellular Adhesion Molecule-1 (ICAM-1). TS can also upregulate Signal Transducer and Activator of Transcription-3 (STAT3), which is an angiogenesis modulator that acts through the IL-6/STAT3 signaling pathway [41]. STAT3 links extracellular signals to transcriptional control of proliferation and cycle progression [42]. Furthermore, TS may also contribute to the upregulation of Apo-lipoprotein E (ApoE) and Serum Amyloid A1 (SAA1) genes. ApoE plays a role in the regulation the lipoprotein metabolism, and it is known to associate with elevated cholesterol and risk of atherosclerosis and ischemic stroke. The transcriptional product of the SAA1 gene is serum amyloid, which is a potent chemoattractant that modulates tissue infiltration and the adhesion of monocytes and leukocytes [43]. In addition, amyloid in brain vessels can enhance BBB permeability [44]. All these events result in the loss of BBB integrity during ischemic insults and contribute toward the development of cerebrovascular diseases. TS can also downregulate claudin- 5 expression, which is an essential interendothelial tight junction protein involved in maintaining the BBB integrity and function. There is considerable controversy regarding the influence of premorbid and comorbid conditions that commonly accompany TBI such as cigarette smoking on the expected rate and extent of recovery from TBI [10]. Indeed, considering the influence of premorbid and comorbid 
conditions may lead to spurious conclusions about the mechanisms underlying the pathophysiology of the TBI [10].

\section{Pathophysiology and Underlying Causes of TBI}

The pathophysiology of TBI can be divided into primary and secondary injury mechanisms. The primary mechanical injury is due to the physical trauma from a direct head impact. It may result in intracranial and extracranial hemorrhage, tissue destruction, and axonal shearing following damage to the blood vessels, brain tissue, and the BBB [15,45]. Within a variable period (days to months and sometimes even years) after the onset of the initial injury, secondary injury usually occurs. The pathogenic events unfolding during the onset of the secondary damage ultimately compromise cell and tissue viability at the metabolic and molecular levels [23]. Cerebral edema formation and the increase of intracranial pressure are other critical factors that are prodromal to secondary brain injury [15]. There are several neurotransmitters, biochemical mediators, cytokines, and genetic changes that play a pivotal role in the molecular mechanisms of tissue injury after TBI [46]. This pro-inflammatory environment (promoting OS and the increased expression of endothelial cell adhesion molecules) facilitates the activation and the influx of immune cells into the brain parenchyma, thus determining the progression of injury, including excitotoxicity and neuronal loss [25,47,48]. Although the primary brain injury is the initial pathogenic factor, the secondary brain injury is generally more severe and complex and promotes the expansion of the initial mechanical brain injury in surrounding healthy tissue $[20,24,49,50]$. Several studies reported that TBI chronically leads to the onset of various cerebrovascular and neurodegenerative disorders such as Alzheimer's disease, chronic traumatic encephalopathy, and epilepsy as well as other long-term problems, including the loss of executive function, inappropriate social behavior, and cognitive disabilities [51-53].

\section{TBI and Breakdown of the BBB}

BBB disruption is a major pathophysiological feature of TBI and is associated with neuroinflammatory events contributing to brain edema and cell death [2]. Due to the highly heterogeneous characteristic of the brain, in response to a direct impact or external forces applied to the head, different brain structures are subject to different acceleration rates, resulting in the generation of considerable tensile, shear, and compressive forces within the brain.

Both astrocytes and microglia can rapidly respond to injury by increasing the production of multiple factors that may have a significant effect on BBB function [30]. The BBB permeability is mainly modulated by the expression of tight junctional proteins on endothelial cells [2]. However, the primary injury of TBI leads to damaged endothelial cells and a loss of blood flow followed by disrupted tight junctional proteins and the basal membrane, thus leading to a loss of barrier integrity and subsequent elevated permeability [25] (see also Figure 2). BBB breakdown not only triggers leukocyte recruitment and the migration of inflammatory cells activating astrocytes, but it also causes the release of pro-inflammatory cytokines, cytotoxic proteases, and reactive oxygen species (ROS) to activate microglia, affecting neuronal activity [15]. A physical barrier termed "glial scar" forms around the damaged area to protect the surrounding intact neural tissue from the destructive immunoresponse and prevent the spread of inflammation to neighboring neurons and undamaged areas.

Moreover, local inflammation occurs, expanding the site of injury and exacerbating the damage [3]. The glial scar encloses an area containing inhibitory molecules that impede the regrowth of neurons and block the repair of the BBB $[4,15]$. Furthermore, disruption of the BBB after TBI promotes the activation of the coagulation cascade, resulting in the formation of an intravascular blood clot and ischemia [2]. In addition, the reduced integrity of the BBB enables the efflux of plasma proteins into the extravascular space. This latter efflux ultimately induces neuroinflammation by promoting the activation of transforming growth factor $\beta$ (TGF- $\beta$ ) [54]. 


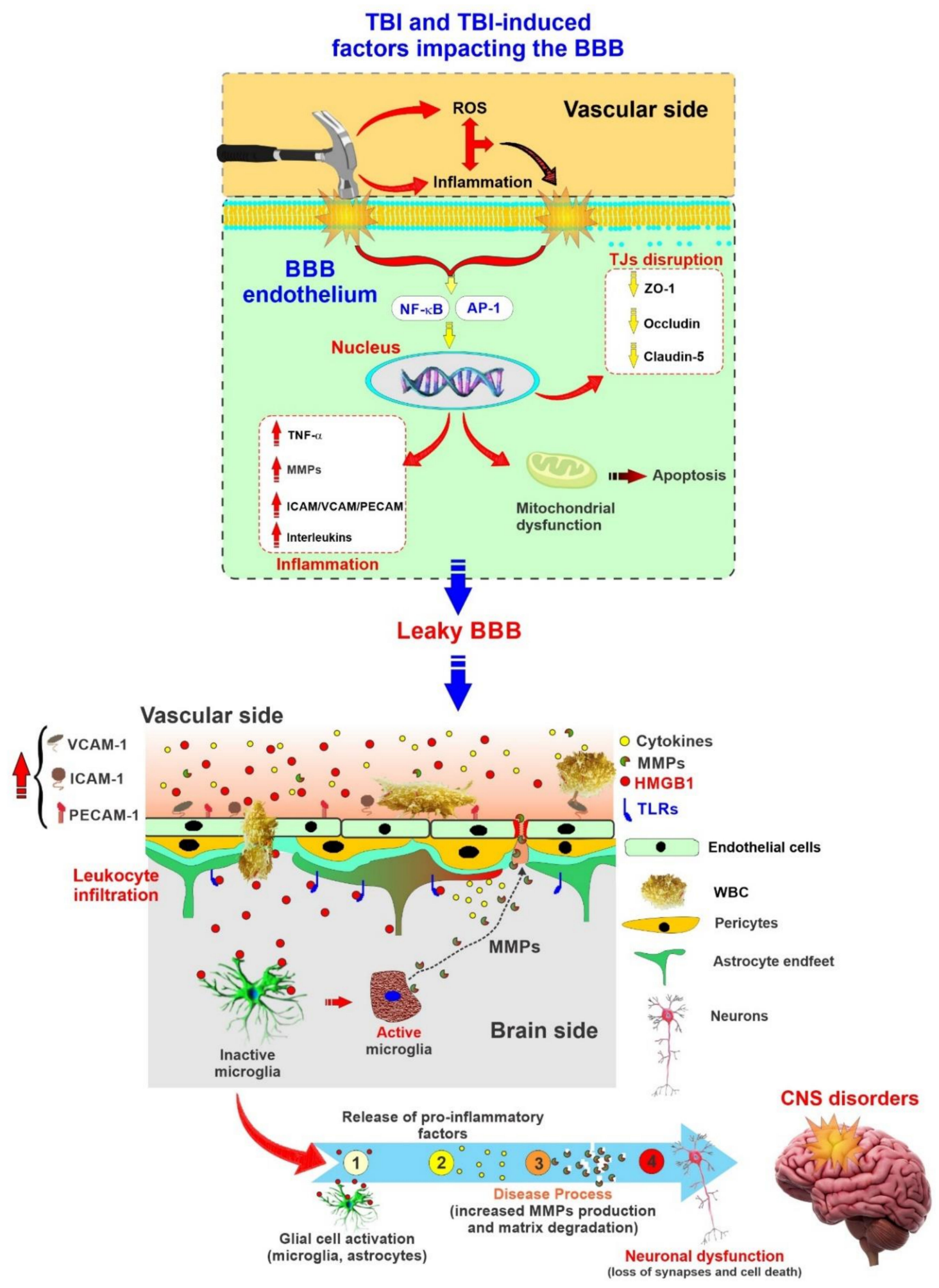

Figure 2. Schematic illustration depicting TBI and TBI-depending factors impacting the BBB and the onset of secondary brain injuries. Representation of BBB as a source and target of neuroinflammation in TBI. Note that inflammation and reactive oxygen species (ROS) generation associated with TBI can further impact the BBB in addition to mechanical trauma. The loss of BBB integrity further promotes neuronal damage and the onset of central nervous system (CNS) disorders.

These studies suggest that there is a strong association between the degree of BBB disruption and onset of neuroinflammatory processes caused by circulating immune cells and the influx of 
neutrophils into the damaged area of the CNS [2]. This set of events promotes the onset of a vicious cycle, which helps further damage to the BBB. On the other hand, a leakier BBB may facilitate the efflux of water from the brain parenchyma, thus reducing post-TBI cerebral edema [2]. In fact, researchers have demonstrated that transient and size-selective modulation in the BBB paradoxically enhances the movement of water from the brain parenchyma to the blood vessels, leading to decreased brain swelling [55].

\section{Post-TBI Cell Death Mechanisms}

Mechanisms of neuronal cell death post-TBI have been mainly categorized into necrosis and apoptosis, while there are at least a dozen mechanisms of neuronal death including intrinsic and extrinsic apoptosis, oncosis, necroptosis, parthanatos, ferroptosis, sarmoptosis, autophagic cell death, autosis, autolysis, paraptosis, pyroptosis, phagoptosis, and mitochondrial permeability transition [56]. Necrosis is defined as a passive process characterized by the loss of ionic balance and membrane integrity of the cell, leading to cell and intracellular organelle swelling [46]. On the other hand, apoptosis is an energy-consuming process characterized by condensation and fragmentation of the cytoplasm and nucleus with the maintenance of organelle structure, which occurs as programmed cell death and a controlled part of an organism's growth or development [21,46]. TBI promotes the upregulation of many cell-cycle activators such as c-myc, cyclins, and cyclin-dependent kinases, and the downregulation of cell-cycle inhibitors. Moreover, after TBI, caspase-dependent pathways (which play a significant role in cell death) are activated and result in an imbalance between proapoptotic (Bax and Bad) and anti-apoptotic (Blc-2 and Bcl-xL) molecules enhancing cell death [57,58]. Besides, apoptosis-inducing factor (AIF) released into the cytosol, which modulates cell death, causes condensation of chromatin in the periphery of the nucleus along with DNA fragmentation. Studies have shown that the release of AIF is dependent on Poly(ADP-Ribose) Polymerase 1 (PARP-1), causing depletion of cytosolic NAD+ and, consequently, mitochondrial dysfunction and outer membrane permeabilization [46]. It accounts for why PARP-1 inhibition after TBI has proven to be neuroprotective. Autophagic programmed cell death (which is the natural, regulated mechanism of the cell that removes unnecessary or dysfunctional components) involves the lysosomal degradation of organelles and proteins. Autophagy is often the dominant mechanism for programmed cell death in conditions of mitochondrial permeabilization and inhibition of caspases [21].

On the other hand, neuronal cell death is a much more complicated process involving autophagy and paraptosis as well. Paraptosis has a non-apoptotic morphology and is regulated by genes $[59,60]$. Neuronal cell death is categorized in physiologic and excitotoxic [46]. Physiologic cell death refers to a developmental death due to injuries such as ethanol or TBI and is characterized by initial mitochondrial swelling followed by vacuolization of the endoplasmic reticulum after rupture of the nuclear membrane. Excitotoxic cell death (often seen in a few hours after TBI) refers to the rapid swelling and rupture of organelles along with the clumping of chromatin in the center of the nucleus [61,62].

Autophagy is one of the main types of neuronal death after TBI [63]. Autophagy flux occurs with the fusion of the autophagosome with the lysosome to form autolysosomes, which degrades the cytoplasmic organoids [64]. Three general methods to detect autophagic flux are Microtubule-associated protein 1A/1B-light chain 3 (LC3) turnover, protein p62 degradation, and tandem fluorescent tagged LC3 (tfLC3) assay [65]. Autophagy has a dual role in TBI, depending on its flux [66]. In mild cases, autophagy flux is increased, which is expected to be beneficial for cell survival. Conversely, flux is decreased in moderate to severe cases, which leads to neuronal death and aggravated pathological phenotypes [66]. Increased LC3-II and autophagosomes are observed in the experimental weight drop injury model of TBI [67], and caloric restriction after mild TBI results in increased Beclin 1, LC3, and mTOR [68]. TBI could inhibit PI3K/AKT/mTOR pathway [69], NRF2/ARE pathway [50], TLR4/NF- KB pathway [70], and activate FoxO3a [71] and Drp1 [72] proteins, which are in the upstream of autophagy and their regulation by TBI may promote autophagosome formation and cause BBB disruption [66]. 


\section{Excitotoxicity}

Cellular excitotoxicity is a pathological process by which neuron cells are damaged by excessive neurotransmitters stimulation such as glutamate and other excitatory factors. Cellular excitotoxicity, which is a crucial mediator in the pathophysiology of TBI, primarily occurs as a result of upregulated $\mathrm{N}$-methyl-D-aspartic acid (NMDA) and $\alpha$-amino-3-hydroxy5-methyl-4-isoxazole -propionic acid (AMPA) receptors [73]. Raised glutamate released from parenchymal brain cells activates the AMPA receptors, prompting the receptor-associated ion channels to open, thus upregulating the influx of sodium and calcium ions [2,74]. Glutamate levels are the highest immediately after TBI, and these heightened levels are sustained for $24-48 \mathrm{~h}$ due to the disruption of the BBB [75]. In addition, there is some evidence that glutamate promotes ROS production [76,77].

There are some other molecules, including TGF- $\beta$, vascular endothelial growth factor (VEGF), and matrix metalloproteinases (MMPs), which become abnormally elevated in the brain following TBI, thus contributing to BBB impairment and the loss of barrier integrity [2]. The damage to the BBB will eventually facilitate the development of cerebral edema and the onset of other post-TBI secondary injuries [2]. Specifically, recent studies have revealed the increased synthesis and elevated levels of MMPs as well as a reduced expression of MMPs inhibitors and endogenous MMPs regulators in plasma and the cerebrospinal fluid (CSF) of brain tissue from TBI patients and animal models of TBI.

Moreover, the upregulation of VEGF, as a major regulator of endothelial cell proliferation, angiogenesis, and vascular permeability as well as the downregulation of claudin- 5 expression was correlated to BBB dysfunction $[26,33,78,79]$.

TGF- $\beta$, as a molecule with a pivotal role in cell proliferation and differentiation, gets released in large amounts from platelets after vascular wall damage. Several studies have shown that there is an increase in the expression of both TGF- $\beta$ and TGF- $\beta$ receptors on vascular endothelium post-TBI. There are conflicting studies regarding the positive or negative impact of TGF- $\beta$ on BBB permeability, so some believe TGF- $\beta$ plays a role in maintaining BBB integrity through stabilizing endothelial cell and pericyte interaction via N-cadherin. Other studies instead suggest that TGF- $\beta$ derived-tyrosine phosphorylation reduces claudin-5 and VE-cadherin expression [80,81].

\section{Neuroinflammation}

Neuroinflammatory responses to injury have a significant pathophysiological role in the development of post-TBI secondary brain damage (although its role in primary injury is limited). Immediately after the impact, the mechanical disruption of the BBB causes the extravasation of red blood cells, accompanied by a limited influx of leukocytes due to the rapid activation of the coagulation cascade. The process results in a significant reduction in blood flow in affected brain tissue [30]. Neuroinflammation involves the influx of leukocytes into the injured brain parenchyma penetrating across the BBB. This is followed by the influx of neutrophils, monocytes, and lymphocytes within a relatively short period of time (hours to days) post-TBI [82-84]. During this critical time frame, the production of inflammatory mediators, including cytokines (such as IL-6, IL-10, TNF- $\alpha$, and IL-1 $\beta$ ) increases. Following the cytokines' upregulation, cell adhesion molecules expressed on the surface of the cerebrovascular endothelium also increase. All of these processes eventually lead to the influx of inflammatory cells from the blood into the brain to initiate a host of restorative processes, including neurogenesis, synaptogenesis, oligodendrogenesis, and angiogenesis taking place in the brain as the spontaneous functional recovery after TBI [85-90]. Another factor of relevance is that the activation of microglial cells not only causes the amplification of the inflammatory response but also ROS production along with neurotoxic molecules. The result is the onset of other secondary mechanisms of cell death [83].

As mentioned previously, cytokines are pro-inflammatory mediators that include interferons, interleukins, and chemokines secreted from immune cells [91]. Based on recent in vivo studies, the synthesis of pro-inflammatory cytokines is rapidly upregulated in rodent models of TBI [30]. Among the major cytokines, TNF- $\alpha$ and IL- $1 \beta$ play a vital role in exacerbating tissue damage; thus, 
there is a dose-response correlation between the cytokines expression level and mortality, including intracranial pressure and multiorgan failure [46]. While TNF- $\alpha$ increases as early as one hour after TBI, IL-1 $\beta$ upregulates gradually to reach a peak at $6-8 \mathrm{~h}$ post-TBI. Pro-inflammatory cytokines also have multiple effects on the BBB, where they promote loss of barrier integrity, downregulation and altered distribution of tight junctional proteins, and ROS production [25,92]. Moreover, further details have revealed that TNF- $\alpha$ enhances the formation of actin stress fibers, which is followed by cell retraction and formation of intercellular gaps. In addition to the detrimental effect on BBB viability, the most critical role of these pro-inflammatory mediators is inducing the synthesis of chemokine as well as the expression of cell adhesion molecules on the surface of the endothelial layer. In several studies on human brain microvascular endothelial cells, it has been demonstrated that cells exposed to TNF- $\alpha$ or IL-1 $\beta$ promoted the expression of E-selectin, Intercellular Adhesion Molecule 1 (ICAM1), and vascular cell adhesion molecule-1 (VCAM1) on the cell surface [30]. Furthermore, the rapid induction of endothelial expression of E-selectin and an upregulated expression of ICAM1 post-TBI have been reported in both clinical and animal studies and have been positively correlated with increasing severity of the injury and worsening neurological outcome.

Nuclear factor kappa-light chain-enhancer of activated B cells (NF-kB) is a protein complex that controls pro-inflammatory cytokine production in most cell types, including neurons, astrocytes, microglia, oligodendrocytes, and endothelial cells of neurovascular and cerebrovascular units [21]. Recent studies have demonstrated a critical physiological role for the NF-kB signaling pathway in the central nervous system, serving crucial functions in cellular responses to neuronal injury [93-95]. It is well established that post-TBI leads to the activation of NF- $\mathrm{kB}$ in glial cells and neurons in the same brain region undergoing atrophy, which is associated with inflammatory processes. Moreover, it is reported that repression of the NF- $\mathrm{KB}$ inhibitor system in an experimental model of TBI promoted neuronal cell death, worsens the neurological outcome, and increased the post-TBI mortality rate [96].

\section{Cerebral Edema Formation}

Cerebral edema is among the very significant secondary injury consequences of TBI and the leading cause of death in more than half of all deaths after severe TBI [15]. Understanding the development of cerebral edema is crucial because it considerably affects the high morbidity and mortality after TBI [2]. Post-traumatic cerebral edema caused the expansion of brain volume against an enclosed skull and raised intracranial pressure inside the unyielding cranial cavity, causing herniation and a reduction in cerebral perfusion pressure, promoting cerebral ischemia [97]. According to valid studies, cerebral edema results from a combination of endothelial cell damage, tight junction disruption, and abnormal transcellular transport due to vessel damage resulting in interstitial accumulation of plasma-derived, osmotically active molecules followed by water [30,55]. Cerebral edema could also be caused by changes in cell metabolism and the failure of membrane-associated pumps and ion transporters, resulting in the cellular accumulation of osmotically active molecules followed by water [2].

\section{Oxidative Stress and Influence of Cigarette Smoking on the Pathophysiology of TBI}

Excessive ROS production following cell damage, neuronal cell death, and brain dysfunction are the results of several secondary biochemical and metabolic changes in the cells [24]. Oxidative stress, which results from the unhindered generation of ROS, has been known as the major pathophysiological mechanism responsible for secondary injury post-TBI [98]. Post-traumatic oxidative stress leads to the peroxidation of membrane polyunsaturated fatty acids, protein carbonylation, and DNA oxidation through ROS, which may affect the BBB permeability and fluidity, leading to membrane damage and eventual apoptosis and tissue necrosis [99-101]. Antioxidant mechanisms, including superoxide dehydrogenase, catalase, and peroxidases, are often detrimentally affected by TBI, which leads to increased oxidative injury [102]. There is evidence that the interstitial level of hydroxyl radicals increases rapidly after TBI, and it may play a significant role in the lipid peroxidation of the membrane, eventually causing highly active aldehydes, such as 4-hydroxynonenal (4-HNE) [30]. Several in vitro 
and in vivo models of the BBB have shown that 4-HNE significantly increases BBB permeability. At the same time, the administration of lipid peroxidation inhibitor reduces the post-traumatic increase in BBB permeability. Normal BBB function is highly dependent on the ability of BBB to protect themselves from noxious effects of ROS through endogenous molecules such as glutathione (GSH). The pharmacological depletion of GSH significantly increases the paracellular BBB to low molecular weight substances. The exposure of the BBB to a mixture of ROS predominantly containing superoxide anion radicals (produced as a result of NADPH oxidase (Nox) upregulation), hydroxyl radicals, and hydrogen peroxide was shown to rapidly increase the BBB permeability. The loss of BBB integrity was associated with the redistribution and degradation of tight junctional proteins, as well as DNA degradation and lipid peroxidation $[17,101]$. It is well known that nitric oxide rapidly reacts with superoxide anion radical, resulting in a variety of free radicals and eventually oxidative stress. Although the cerebrovascular endothelium itself produces nitric oxide in small quantities, the exposure to moderate to the high amount of nitric oxide significantly promotes the paracellular permeability of BBB [30]. Moreover, oxidative stress may play a significant role in promoting post-traumatic neuroinflammation as a result of increased adhesion and migration of monocytic cells as well as the expression of intercellular adhesion molecules across the endothelial monolayers. Furthermore, bradykinin is known as a promoter of ROS production so that it activates phospholipase A2, which induces Nox activity, further leading to ROS production [25]. It has been proven Nox inhibitors are able to reduce inflammation, neuronal degeneration, oxidative stress, and cerebral edema post-TBI [103,104].

According to recent studies, NRF2 plays a significant neuroprotective role in TBI and other neurodegenerative disorders so that NRF2 activation counteracts TBI-induced OS, loss of BBB integrity, etc. $[20,22]$. Unsurprisingly, impairments of the NRF2-ARE pathway leading to the reduced activity of this protective system can lead to more extensive post-TBI tissue damage, thus aggravating the secondary injury and worsening the outcome. Accordingly, the upregulation of NRF2 expression could be exploited to reduce post-TBI outcomes [80]. TBI-induced brain damage provides a viable strategy to treat post-traumatic brain injuries, improve clinical outcomes, and reduce the risk of additional neurological disorders through the reduction of oxidative stress and post-traumatic inflammatory responses [105-107].

\section{Current Treatments of TBI}

Millions of people in the United States have been suffering through chronic symptoms of TBI [108]. While TBI is a prominent health crisis that faced global public health leading to very high mortality and morbidity, unfortunately, there has been a lack of effective therapeutic options for the management of TBI cases. However, some nutritional components and therapeutic agents have currently been utilized for the treatment of the symptoms at earlier stages of TBI.

Elevated calcium levels play an essential role in the cascade of cellular damage after TBI [109]. Thus, the use of calcium channel blockers has been proposed for the prevention of or treatment after cerebral brain injury, causing secondary brain damage due to a reduction in blood flow [110]. Nimodipine and ziconotide are drugs that can block L- and N-type calcium channels, respectively. Based on recent studies, the administration of nimodipine regulates brain perfusion and prevents further neuronal damage, resulting in improved symptoms of TBI patients who have subarachnoid hemorrhage [110]. Similarly, in a rat model, it has been shown that if ziconotide was administered within $15 \mathrm{~min}$ to $6 \mathrm{~h}$ of TBI, it leads to improved mitochondrial function as well as motor and cognitive activities [111,112]. It is noteworthy that in spite of the beneficial effect of nimodipine on brain injury patients with subarachnoid hemorrhage, the increase in adverse reactions may mean that the drug is harmful to some patients [110].

Brain swelling in TBI patients may cause dangerous pressure on the brain (increased intracranial pressure (ICP)). Mannitol, which is a naturally occurring alcohol found in fruits and vegetables and used as an osmotic diuretic, has demonstrated a beneficial role in reducing ICP and inflammatory response as well as improving blood perfusion in a dose-dependent manner [109,113]. In contrast, 
it is revealed that although mannitol reverses the swelling at first, its prolonged use can eventually worsen the pressure [114]. Therefore, additional evidence is necessary to show whether administrating mannitol leads to the improvement of post-TBI outcomes.

Amantadine is one of the most prescribed medications for patients with prolonged disorders of consciousness after TBI. Based on several studies, amantadine accelerates the pace of functional recovery during active treatment in patients with post-TBI disorders of consciousness [115]. Besides, in the acute phase of TBI, neurons can be protected from glutamatergic excitation by administering amantadine as its action as an NMDA antagonist in frontal lobes and may improve cognition [116]. Although amantadine showed generally improved conditions in TBI patients, in several studies, no differences were found in the rate of cognitive improvement between subjects given amantadine versus those given placebo.

Neurons majorly lose their function, leading to death during secondary brain injury, which has a series of consecutive pathological processes resulting from oxidative stress $[49,117]$. The metabolism of biological macromolecules produces excessive ROS that intensely damages neurons after TBI [24]. NRF2 as a critical regulator protein that prevents oxidative stress damage due to injury and/or inflammation after TBI [118]. Thus, its activation may attenuate post-TBI pathophysiologic phenomena, i.e., neuronal apoptosis cerebral edema and cognitive deficits. Indeed, recent promising studies encourage the utilization of NRF2 as a targeted therapy for the patients suffering from TBI.

Curcumin, a polyphenol derived from Curcuma longa rhizomes, has been examined for the underlying mechanism behind its neuroprotective role in secondary brain damage after TBI $[22,119,120]$. The beneficial effects of curcumin are not only is due to its ability to cross the BBB, but also it has been linked to the activation of NRF2 as well as superoxide dismutase and glutathione peroxidase [21,121-126]. Recent studies have also revealed that curcumin lessened brain edema and oxidative damage by enhancing NRF2 expression and [22,127,128] antioxidant enzymes, i.e., Nqo1, Hmox1 Gclm, and Gclc, as well as down-regulating NF-kB. Additionally, several studies have indicated that curcumin could promote membrane and energy homeostasis and influence synaptic plasticity following TBI $[129,130]$.

Sulforaphane (SFN), a well-known NRF2 promoter/activator, is an organic isothiocyanate naturally found in cruciferous plants such as broccoli and cabbage. SFN has been shown to possess neuroprotective properties in vitro as well as in vivo by activating the NRF2-KEAP1 pathway and enhancing the corresponding protein synthesis [122,131-139]. Several studies revealed that in addition to the activation of NRF2, SFN could independently inhibit NF-kB activity. SFN has been shown to inhibit TNF-alpha-induced NF-kB activation through the inhibition of IkB- $\alpha$ phosphorylation, degradation, and p65 nuclear translocation, thus preventing cell apoptosis [140]. Moreover, SFN was shown to be able to block the direct interaction between NF-kB and its consensus sequence, suppressing its pro-inflammatory activities in T cells [141].

Metformin (MF) is a biguanide oral anti-hyperglycemic agent derived from the plant Galega Officinalis and used to treat patients with type-2 diabetes (non-insulin dependent). MF has also been shown to attenuate BBB disruption via AMPK-dependent and independent (NRF2 antioxidant pathway) mechanisms [142,143]. Recent studies revealed that NRF2 plays a protective role in TS-induced cerebrovascular/BBB impairments by normalizing TJs proteins expression, restoring the BBB integrity, and decreasing oxidative stress and inflammation, which all leads to a reduced burden of TS cerebrovascular toxicity [144]. Not surprisingly, MF has also been shown to concurrently inhibit $\mathrm{NF}-\mathrm{kB}$ activation, thus preventing the cytokine-induced expression of pro-inflammatory and adhesion molecules in vascular endothelial cells [145-148]. These studies highlight the additional MF therapeutic potential outside the treatment of diabetes $[149,150]$. These findings highlight the other MF therapeutic potential outside the treatment of diabetes for the treatment of cerebrovascular and neuroinflammatory disorders associated with oxidative stress and inflammation, primarily due to its dual effect as an NRF2 activator and NF- $\mathrm{KB}$ inhibitor [144,151-153]. 
Ramelteon is a melatonin receptor agonist that is used to treat sleep disturbance in patients with TBI. In recent studies on TBI, ramelteon has demonstrated antioxidant and anti-inflammatory properties $[154,155]$. Timed ramelteon treatment appeared to protect the brain after TBI by preventing inflammation. This effect seems to be mediated by a drug-dependent increase of anti-inflammatory cytokines and the activation of the NRF2-ARE signaling pathway $[154,155]$. Thus, it seems that ramelteon could be considered as a potential chronotherapeutic strategy for treating TBI.

A huge number of drugs with anti-inflammatory action have been investigated in both preclinical and clinical studies. Mostly, these drugs are categorized into either anti-inflammatory inducers or inflammatory inhibitors [156]. Interestingly, the efficacy of anti-inflammatory drugs is directly assessed through the reduced number and activation state of inflammatory cells as well as changes in the levels of anti-inflammatory mediators. In an outstanding review paper, Bergold has provided a comprehensive review on the results of both preclinical studies and clinical trials of anti-inflammatory drugs [156].

\section{Conclusions}

The consequences of TBI are a growing concern in the United States. Despite vast studies, the mechanisms and therapeutic strategies to alleviate the impacts of TBI have not been fully understood. Excitotoxicity, oxidative stress, cerebral edema formation, neuroinflammation, and cytokine are prominent mechanisms of cell damage and death post-TBI. Several novel promising strategies to treat TBI are successfully targeting the stabilization of BBB integrity. The safekeeping of BBB function could have a significant therapeutic relevance to improve TBI outcomes and reduce secondary injury. Indeed, regulating post-traumatic BBB dysfunction would play an active role in the reduction of morbidity and mortality from TBI. This is even more relevant in patients with premorbid conditions (such as chronic smoking), which have detrimental effects on BBB function and immune responses. Although the therapeutic window of BBB regulation after TBI remains unknown, further elucidation of the dynamics of BBB dysfunction after TBI would provide significant knowledge for novel specific therapies, the selection of therapeutic agents, and the timing of treatment. Future investigations might determine how to effectively engage the cerebrovascular endothelium to produce neuroprotective growth factors that can act on nearby neurons. As the understanding of the complex cellular and molecular interactions within the gliovascular unit grows, it is likely that more opportunities for interventions that are directed at the BBB will arise.

Author Contributions: F.S. and F.A. conceived the study and prepared the drafting of the manuscript. L.C. oversaw the entire project, assisted with the writing of the manuscript and preparation of the figures, and provided funding support. All authors reviewed the manuscript. All authors have read and agreed to the published version of the manuscript.

Funding: This work was supported by the National Institutes of Health/National Institute on Drug Abuse 2R01DA029121 and 1R01DA049737 to L.C.

Conflicts of Interest: The authors declare no conflicts of interest.

\section{Abbreviations}

$\begin{array}{ll}\text { 4-HNE } & \text { 4-hydroxynonenal } \\ \text { AJ } & \text { Adherens junctions } \\ \text { AMPA } & \alpha \text {-amino-3-hydroxy5-methyl-4-isoxazole-propionic acid } \\ \text { ApoE } & \text { Apo-lipoprotein E } \\ \text { BBB } & \text { Blood-Brain Barrier } \\ \text { BCRP } & \text { Breast-cancer-resistance protein } \\ \text { CNS } & \text { Central nervous system } \\ \text { CDC } & \text { lefts for Disease Control and Prevention } \\ \text { FTC } & \text { Federal Trade Control } \\ \text { ICAM1 } & \text { Intercellular adhesion molecule } 1\end{array}$




$\begin{array}{ll}\text { IL-6 } & \text { Interleukin-6 } \\ \text { MF } & \text { Metformin } \\ \text { MMP-2 } & \text { Matrix metalloproteinase-2 } \\ \text { MRP } & \text { Multidrug-resistant protein } \\ \text { NAD(P)H } & \text { Quinone reductase I } \\ \text { NF-kB } & \text { Nuclear factor kappa-light chain-enhancer of activated B cells } \\ \text { NMDA } & \text { N-methyl-D-aspartic acid } \\ \text { NRF2 } & \text { Nuclear factor erythroid 2-related factor } \\ \text { OS } & \text { Oxidative stress } \\ \text { PARP1 } & \text { Poly(ADP-Ribose) polymerase 1 } \\ \text { PECAM-1 } & \text { Platelet Endothelial Cell Adhesion Molecule-1 } \\ \text { Pgp } & \text { P-glycoprotein } \\ \text { ROS } & \text { Reactive oxygen species } \\ \text { SAA1 } & \text { Serum Amyloid A1 } \\ \text { SCSM } & \text { Single cigarette smoking machine } \\ \text { STAT3 } & \text { Signal Transducer and Activator Of Transcription-3 } \\ \text { SFN } & \text { Sulforaphane } \\ \text { TBI } & \text { Traumatic Brain Injury } \\ \text { TGF- } \beta & \text { transforming growth factor } \beta \\ \text { TJ } & \text { Tight Junction } \\ \text { TNF- } \alpha & \text { tumor necrosis factor-alpha } \\ \text { TS } & \text { Tobacco smoke } \\ \text { VCAM1 } & \text { Vascular cell adhesion molecule-1 } \\ \text { VEGF } & \text { vascular endothelial growth factor } \\ \text { ZO-1 } & \text { Zonula occludens-1 } \\ \end{array}$

\section{References}

1. Sharma, R.; Shultz, S.R.; Robinson, M.; Belli, A.; Hibbs, M.L.; O’Brien, T.J.; Semple, B.D. Infections after a traumatic brain injury: The complex interplay between the immune and neurological systems. Brain Behav. Immun. 2019, 79, 63-74. [CrossRef] [PubMed]

2. Price, L.; Wilson, C.; Grant, A.G. Blood-brain barrier pathophysiology following traumatic brain injury. In Translational Research in Traumatic Brain Injury; CRC Press: Boca Raton, FL, USA, 2015; pp. 85-96. [CrossRef]

3. Sivandzade, F.; Cucullo, L. In-vitro blood-brain barrier modeling: A review of modern and fast-advancing technologies. Br. J. Pharmacol. 2018, 38, 1667-1681. [CrossRef] [PubMed]

4. Hasan, A.; Deeb, G.; Rahal, R.; Atwi, K.; Mondello, S.; Mady, H.E.S.M.; Gali, A.; Sleiman, E.; Marei, H.E. Mesenchymal stem cells in the treatment of traumatic brain injury. Front. Neurol. 2017, 8, 341. [CrossRef] [PubMed]

5. Semple, B.D.; Zamani, A.; Rayner, G.; Shultz, S.R.; Jones, N.C. Affective, neurocognitive and psychosocial disorders associated with traumatic brain injury and post-traumatic epilepsy. Neurobiol. Dis. 2019, 123, 27-41. [CrossRef]

6. Laker, S.R. Epidemiology of concussion and mild traumatic brain injury. PM R 2011, 3, S354-S358. [CrossRef]

7. Zhang, L.; Wang, H.; Fan, Y.; Gao, Y.; Li, X.; Hu, Z.; Ding, K.; Wang, Y.; Wang, X. Fucoxanthin provides neuroprotection in models of traumatic brain injury via the Nrf2-ARE and Nrf2-autophagy pathways. Sci. Rep. 2017, 7, 46763. [CrossRef]

8. De La Tremblaye, P.B.; O’Neil, D.A.; Laporte, M.J.; Cheng, J.P.; Beitchman, J.A.; Thomas, T.C.; Bondi, C.O.; Kline, A.E. Elucidating opportunities and pitfalls in the treatment of experimental traumatic brain injury to optimize and facilitate clinical translation. Neurosci. Biobehav. Rev. 2018, 85, 160-175. [CrossRef]

9. Maas, A.; Menon, D.K.; Adelson, P.D.; Andelic, N.; Bell, M.J.; Belli, A.; Bragge, P.; Brazinova, A.; Büki, A.; Chesnut, R.M.; et al. Traumatic brain injury: Integrated approaches to improve prevention, clinical care, and research. Lancet Neurol. 2017, 16, 987-1048. [CrossRef]

10. Durazzo, T.C.; Abadjian, L.; Kincaid, A.; Bilovsky-Muniz, T.; Boreta, L.; Gauger, G.E. The influence of chronic cigarette smoking on neurocognitive recovery after mild traumatic brain injury. J. Neurotrauma 2013, 30, 1013-1022. [CrossRef] 
11. Benady, A.; Freidin, D.; Pick, C.G.; Rubovitch, V. GM1 ganglioside prevents axonal regeneration inhibition and cognitive deficits in a mouse model of traumatic brain injury. Sci. Rep. 2018, 8, 13340. [CrossRef]

12. McAllister, T.W. Neurobiological consequences of traumatic brain injury. Dialog- Clin. Neurosci. 2011, 13, 287-300.

13. Wanner, I.-B.; Anderson, M.A.; Song, B.; Levine, J.; Fernandez, A.; Gray-Thompson, Z.; Ao, Y.; Sofroniew, M.V. Glial scar borders are formed by newly proliferated, elongated astrocytes that interact to corral inflammatory and fibrotic cells via STAT3-dependent mechanisms after spinal cord injury. J. Neurosci. 2013, 33, 12870-12886. [CrossRef] [PubMed]

14. Englander, J.; Cifu, D.X.; Diaz-Arrastia, R.; Center, M.S.K.T. Seizures after traumatic brain injury. Arch. Phys. Med. Rehabil. 2014, 95, 1223-1224. [CrossRef] [PubMed]

15. Thal, S.; Neuhaus, W. The Blood-Brain Barrier as a Target in Traumatic Brain Injury Treatment. Arch. Med. Res. 2014, 45, 698-710. [CrossRef] [PubMed]

16. Amoo, M.; O’Halloran, P.J.; Leo, A.-M.; O'Loughlin, A.; Mahon, P.; Lim, C. Outcomes of emergency neurosurgical intervention in neuro-critical care patients with traumatic brain injury at Cork University Hospital. Br. J. Neurosurg. 2018, 32, 585-589. [CrossRef] [PubMed]

17. Li, W.; Risacher, S.L.; McAllister, T.W.; Saykin, A.J. Traumatic brain injury and age at onset of cognitive impairment in older adults. J. Neurol. 2016, 263, 1280-1285. [CrossRef] [PubMed]

18. Rosenfeld, J.V.; Maas, A.; Bragge, P.; Morganti-Kossmann, M.C.; Manley, G.T.; Gruen, R.L. Early management of severe traumatic brain injury. Lancet 2012, 380, 1088-1098. [CrossRef]

19. Sahyouni, R.; Gutierrez, P.; Gold, E.; Robertson, R.T.; Cummings, B.J. Effects of concussion on the blood-brain barrier in humans and rodents. J. Concussion 2017, 1, 2059700216684518. [CrossRef]

20. Sivandzade, F.; Bhalerao, A.; Cucullo, L. Cerebrovascular and Neurological Disorders: Protective Role of NRF2. Int. J. Mol. Sci. 2019, 20, 3433. [CrossRef]

21. Sivandzade, F.; Prasad, S.; Bhalerao, A.; Cucullo, L. NRF2 and NF-қB interplay in cerebrovascular and neurodegenerative disorders: Molecular mechanisms and possible therapeutic approaches. Redox Boil. 2019, 21, 101059. [CrossRef]

22. Dong, W.; Yang, B.; Wang, L.; Li, B.; Guo, X.; Zhang, M.; Jiang, Z.; Fu, J.; Pi, J.; Guan, D.; et al. Curcumin plays neuroprotective roles against traumatic brain injury partly via Nrf2 signaling. Toxicol. Appl. Pharmacol. 2018, 346, 28-36. [CrossRef] [PubMed]

23. Angeloni, C.; Prata, C.; Sega, F.V.D.; Piperno, R.; Hrelia, S. Traumatic brain injury and NADPH oxidase: A deep relationship. Oxidative Med. Cell. Longev. 2015, 2015, 1-10. [CrossRef] [PubMed]

24. Smith, J.A.; Park, S.; Krause, J.S.; Banik, N. Oxidative stress, DNA damage, and the telomeric complex as therapeutic targets in acute neurodegeneration. Neurochem. Int. 2013, 62, 764-775. [CrossRef] [PubMed]

25. Alves, J.L. Blood-brain barrier and traumatic brain injury. J. Neurosci. Res. 2013, 92, 141-147. [CrossRef]

26. Sivandzade, F.; Cucullo, L. Anti-diabetic countermeasures against tobacco smoke-dependent cerebrovascular toxicity: Use and effect of rosiglitazone. Int. J. Mol. Sci. 2019, 20, 4225. [CrossRef]

27. Freeman, L.R.; Bruce-Keller, A.J. Oxidative stress and cerebral endothelial cells: Regulation of the blood-brain-barrier and antioxidant based interventions. Biochim. Biophys. Acta 2011, 1822, 822-829. [CrossRef]

28. Grammas, P.; Martinez, J.; Miller, B. Cerebral microvascular endothelium and the pathogenesis of neurodegenerative diseases. Expert Rev. Mol. Med. 2011, 13, 13. [CrossRef]

29. Daneman, R.; Prat, A. The blood-brain barrier. Cold Spring Harb. Perspect. Biol. 2015, 7, a020412. [CrossRef]

30. Chodobski, A.; Zink, B.J.; Szmydynger-Chodobska, J. Blood-brain barrier pathophysiology in traumatic brain injury. Transl. Stroke Res. 2011, 2, 492-516. [CrossRef]

31. Erdő, F.; Denes, L.; De Lange, E. Age-associated physiological and pathological changes at the blood-brain barrier: A review. Br. J. Pharmacol. 2016, 37, 4-24. [CrossRef]

32. Broux, B.; Gowing, E.; Prat, A. Glial regulation of the blood-brain barrier in health and disease. Semin. Immunopathol. 2015, 37, 577-590. [CrossRef] [PubMed]

33. Sivandzade, F.; Cucullo, L. Assessing the protective effect of rosiglitazone against electronic cigarette/tobacco smoke-induced blood-brain barrier impairment. BMC Neurosci. 2019, 20, 15. [CrossRef] [PubMed]

34. Jha, P.; Ramasundarahettige, C.; Landsman, V.; Rostron, B.; Thun, M.; Anderson, R.N.; McAfee, T.; Peto, R. 21st-century hazards of smoking and benefits of cessation in the United States. N. Engl. J. Med. 2013, 368, 341-350. [CrossRef] [PubMed] 
35. Kaisar, M.A.; Sivandzade, F.; Bhalerao, A.; Cucullo, L. Conventional and electronic cigarettes dysregulate the expression of iron transporters and detoxifying enzymes at the brain vascular endothelium: In vivo evidence of a gender-specific cellular response to chronic cigarette smoke exposure. Neurosci. Lett. 2018, 682, 1-9. [CrossRef] [PubMed]

36. Sajja, R.K.; Naik, P.; Cucullo, L. Differential cerebrovascular toxicity of various tobacco products: A regulatory perspective. J. Pharmacovigil. 2015, 3, 1-2. [CrossRef]

37. Sajja, R.K.; Rahman, S.; Cucullo, L. Drugs of abuse and blood-brain barrier endothelial dysfunction: A focus on the role of oxidative stress. Br. J. Pharmacol. 2015, 36, 539-554. [CrossRef] [PubMed]

38. Chrissobolis, S. Oxidative stress and endothelial dysfunction in cerebrovascular disease. Front. Biosci. 2011, 16, 1733. [CrossRef]

39. Hossain, M.; Sathe, T.; Fazio, V.; Mazzone, P.; Weksler, B.; Janigro, D.; Rapp, E.; Cucullo, L. Tobacco smoke: A critical etiological factor for vascular impairment at the blood-brain barrier. Brain Res. 2009, 1287, 192-205. [CrossRef]

40. Aseervatham, S.B.; Choi, S.; Krishnan, J.; Kandasamy, R. Cigarette smoke and related risk factors in neurological disorders: An update. Biomed. Pharmacother. 2017, 85, 79-86. [CrossRef]

41. Geraghty, P.P.; Wyman, A.E.M.; Garcia-Arcos, I.P.; Dabo, A.J.M.; Gadhvi, S.M.; Foronjy, R.M. STAT3 modulates cigarette smoke-induced inflammation and protease expression. Front. Physiol. 2013, 4, 267. [CrossRef]

42. Matsuda, T.; Muromoto, R.; Sekine, Y.; Togi, S.; Kitai, Y.; Kon, S.; Oritani, K. Signal transducer and activator of transcription 3 regulation by novel binding partners. World J. Boil. Chem. 2015, 6, 324-332. [CrossRef] [PubMed]

43. Villapol, S.; Kryndushkin, D.; Balarezo, M.G.; Campbell, A.M.; Saavedra, J.M.; Shewmaker, F.P.; Symes, A.J. Hepatic expression of serum amyloid A1 is induced by traumatic brain injury and modulated by telmisartan. Am. J. Pathol. 2015, 185, 2641-2652. [CrossRef] [PubMed]

44. Hartz, A.M.; Bauer, B.; Soldner, E.L.; Wolf, A.; Boy, S.; Backhaus, R.; Mihaljevic, I.; Bogdahn, U.; Klünemann, H.H.; Schuierer, G.; et al. Amyloid- $\beta$ contributes to blood-brain barrier leakage in transgenic human amyloid precursor protein mice and in humans with cerebral amyloid angiopathy. Stroke 2011, 43, 514-523. [CrossRef] [PubMed]

45. Rubovitch, V.; Ten-Bosch, M.; Zohar, O.; Harrison, C.R.; Tempel-Brami, C.; Stein, E.; Hoffer, B.J.; Balaban, C.; Schreiber, S.; Chiu, W.-T.; et al. A mouse model of blast-induced mild traumatic brain injury. Exp. Neurol. 2011, 232, 280-289. [CrossRef]

46. Ladak, A.A.; Enam, S.A.; Ibrahim, M.T. A Review of the Molecular Mechanisms of Traumatic Brain Injury. World Neurosurg. 2019, 131, 126-132. [CrossRef]

47. Quintard, H.; Patet, C.; Suys, T.; Marques-Vidal, P.; Oddo, M. Normobaric Hyperoxia is Associated with Increased Cerebral Excitotoxicity After Severe Traumatic Brain Injury. Neurocrit. Care 2014, 22, 243-250. [CrossRef]

48. Abdul-Muneer, P.M.; Chandra, N.; Haorah, J. Interactions of Oxidative Stress and Neurovascular Inflammation in the Pathogenesis of Traumatic Brain Injury. Mol. Neurobiol. 2014, 51, 966-979. [CrossRef]

49. Cornelius, C.; Crupi, R.; Calabrese, V.; Graziano, A.; Milone, P.; Pennisi, G.; Radak, Z.; Calabrese, E.J.; Cuzzocrea, S. Traumatic Brain Injury: Oxidative Stress and Neuroprotection. Antioxid. Redox Signal. 2013, 19, 836-853. [CrossRef]

50. Ding, K.; Wang, H.; Xu, J.; Li, T.; Zhang, L.; Ding, Y.; Zhu, L.; He, J.; Zhou, M. Melatonin stimulates antioxidant enzymes and reduces oxidative stress in experimental traumatic brain injury: The Nrf2-ARE signaling pathway as a potential mechanism. Free. Radic. Boil. Med. 2014, 73, 1-11. [CrossRef]

51. Pop, V.; Badaut, J. A Neurovascular Perspective for Long-Term Changes After Brain Trauma. Transl. Stroke Res. 2011, 2, 533-545. [CrossRef]

52. Tagge, C.; Fisher, A.M.; Minaeva, O.V.; Gaudreau-Balderrama, A.; Moncaster, J.; Zhang, X.-L.; Wojnarowicz, M.W.; Casey, N.; Lu, H.; Kokiko-Cochran, O.N.; et al. Concussion, microvascular injury, and early tauopathy in young athletes after impact head injury and an impact concussion mouse model. Brain 2018, 141, 422-458. [CrossRef] [PubMed]

53. Dulla, C.G.; Coulter, U.A.; Žiburkus, J. From Molecular Circuit Dysfunction to Disease: Case Studies in Epilepsy, Traumatic Brain Injury and Alzheimer's Disease. Neuroscientist 2015, 22, 295-312. [CrossRef] [PubMed] 
54. Muradashvili, N.; Lominadze, D. Role of fibrinogen in cerebrovascular dysfunction after traumatic brain injury. Brain Inj. 2013, 27, 1508-1515. [CrossRef] [PubMed]

55. Campbell, M.; Hanrahan, F.; Gobbo, O.; Kelly, M.E.; Kiang, A.-S.; Humphries, M.M.; Nguyen, A.T.; Ozaki, E.; Keaney, J.; Blau, C.W.; et al. Targeted suppression of claudin-5 decreases cerebral oedema and improves cognitive outcome following traumatic brain injury. Nat. Commun. 2012, 3, 849. [CrossRef] [PubMed]

56. Borutaite, V.; Tolkovsky, A.M.; Fricker, M.; Brown, G.C.; Coleman, M. Neuronal Cell Death. Physiol. Rev. 2018, 98, 813-880.

57. Sun, G.-Z.; Gao, F.-F.; Zhao, Z.-M.; Sun, H.; Xu, W.; Wu, L.-W.; He, Y.-C. Endoplasmic reticulum stress-induced apoptosis in the penumbra aggravates secondary damage in rats with traumatic brain injury. Neural Regen. Res. 2016, 11, 1260-1266. [CrossRef]

58. Liu, G.; Zou, H.; Luo, T.; Long, M.; Bian, J.; Liu, X.; Gu, J.; Yuan, Y.; Song, R.; Wang, Y.; et al. Caspase-dependent and caspase-independent pathways are involved in cadmium-induced apoptosis in primary rat proximal tubular cell culture. PLoS ONE 2016, 11, e0166823. [CrossRef]

59. Sperandio, S.; Poksay, K.S.; Schilling, B.; Crippen, D.; Gibson, B.W.; Bredesen, D.E. Identification of new modulators and protein alterations in non-apoptotic programmed cell death. J. Cell. Biochem. 2010, 111, 1401-1412. [CrossRef]

60. Wang, Y.; Li, X.; Wang, L.; Ding, P.; Zhang, Y.; Han, W.; Ma, D. An alternative form of paraptosis-like cell death, triggered by TAJ/TROY and enhanced by PDCD5 overexpression. J. Cell Sci. 2004, 117, 1525-1532. [CrossRef]

61. Fujikawa, D. The role of excitotoxic programmed necrosis in acute brain injury. Comput. Struct. Biotechnol. J. 2015, 13, 212-221. [CrossRef]

62. Stoica, B.A.; Faden, A.I. Cell death mechanisms and modulation in traumatic brain injury. Neurotherapeutics 2010, 7, 3-12. [CrossRef] [PubMed]

63. Lai, Y.-C.; Hickey, R.W.; Chen, Y.; Bayir, H.; Sullivan, M.L.; Chu, C.; Kochanek, P.M.; Dixon, C.E.; Jenkins, L.W.; Graham, S.; et al. Autophagy is increased after traumatic brain injury in mice and is partially inhibited by the antioxidant $\gamma$-glutamylcysteinyl ethyl ester. Br. J. Pharmacol. 2007, 28, 540-550. [CrossRef] [PubMed]

64. Loos, B.; Du Toit, A.; Hofmeyr, J.-H.S. Defining and measuring autophagosome flux — concept and reality. Autophagy 2014, 10, 2087-2096. [CrossRef] [PubMed]

65. Zhang, X.-J.; Chen, S.; Huang, K.-X.; Le, W. Why should autophagic flux be assessed? Acta Pharmacol. Sin. 2013, 34, 595-599. [CrossRef] [PubMed]

66. Zhang, L.; Wang, H. Autophagy in traumatic brain injury: A new target for therapeutic intervention. Front. Mol. Neurosci. 2018, 11, 11. [CrossRef] [PubMed]

67. Sun, L.; Gao, J.; Zhao, M.; Jing, X.; Cui, Y.; Xu, X.; Wang, K.; Zhang, W.; Cui, J. The effects of BMSCs transplantation on autophagy by $\mathrm{CX} 43$ in the hippocampus following traumatic brain injury in rats. Neurol. Sci. 2013, 35, 677-682. [CrossRef]

68. Diskin, T.; Tal-Or, P.; Erlich, S.; Mizrachy, L.; Alexandrovich, A.; Shohami, E.; Pinkas-Kramarski, R. Closed head injury induces upregulation of beclin 1 at the cortical site of injury. J. Neurotrauma 2005, 22, 750-762. [CrossRef]

69. Zhang, M.-H.; Zhou, X.-M.; Gao, J.-L.; Wang, K.-J.; Cui, J.-Z. PI3K/Akt/mTOR pathway participates in neuroprotection by dexmedetomidine inhibits neuronic autophagy following traumatic brain injury in rats. Int. J. Res. Med. Sci. 2014, 2, 1569-1575. [CrossRef]

70. Chen, X.; Wu, S.; Chen, C.; Xie, B.; Fang, Z.; Hu, W.; Chen, J.; Fu, H.; He, H. Omega-3 polyunsaturated fatty acid supplementation attenuates microglial-induced inflammation by inhibiting the HMGB1/TLR4/NF- $\mathrm{kB}$ pathway following experimental traumatic brain injury. J. Neuroinflamm. 2017, 14, 143. [CrossRef]

71. Kapoor, S.; Kim, S.-M.; Farook, J.M.; Mir, S.; Saha, R.; Sen, N. Foxo3a transcriptionally upregulates AQP4 and induces cerebral edema following traumatic brain injury. J. Neurosci. 2013, 33, 17398-17403. [CrossRef]

72. Song, Y.; Li, T.; Liu, Z.; Xu, Z.; Zhang, Z.; Chi, L.; Liu, Y. Inhibition of Drp1 after traumatic brain injury provides brain protection and improves behavioral performance in rats. Chem. Biol. Interact. 2019, 304, 173-185. [CrossRef] [PubMed]

73. Borlongan, C.V.; Acosta, S.; Pena, I.D.; Tajiri, N.; Kaneko, Y.; Lozano, D.; Gonzales-Portillo, G.S. Neuroinflammatory responses to traumatic brain injury: Etiology, clinical consequences, and therapeutic opportunities. Neuropsychiatr. Dis. Treat. 2015, 11, 97-106. [CrossRef] [PubMed] 
74. Gao, L. Fbsbioscience.Org Traumatic brain injury a review of characteristics molecular basis and management. Front. Biosci. 2016, 21, 890-899. [CrossRef] [PubMed]

75. Tasker, R.C. Spreading depolarisations and traumatic brain injury: Time course and mechanisms. Lancet Neurol. 2012, 11, 389-390. [CrossRef]

76. Park, J.-Y.; Amarsanaa, K.; Cui, Y.; Lee, J.-H.; Wu, J.; Yang, Y.-S.; Eun, S.-Y.; Jung, S.-C. Methyl lucidone exhibits neuroprotective effects on glutamate-induced oxidative stress in HT-22 cells via Nrf-2/HO-1 signaling. Appl. Biol. Chem. 2019, 62,1-9. [CrossRef]

77. Xin, H.; Cui, Y.; An, Z.; Yang, Q.; Zou, X.; Yu, N. Attenuated glutamate induced ROS production by antioxidative compounds in neural cell lines. RSC Adv. 2019, 9, 34735-34743. [CrossRef]

78. Nag, S.; Manias, J.; Eubanks, J.H.; Stewart, D.J. Increased expression of vascular endothelial growth factor-D following brain injury. Int. J. Mol. Sci. 2019, 20, 1594. [CrossRef]

79. Suzuki, Y.; Nagai, N.; Umemura, K. A review of the mechanisms of blood-brain barrier permeability by tissue-type plasminogen activator treatment for cerebral ischemia. Front. Cell. Neurosci. 2016, 10, 95. [CrossRef]

80. Shen, W.; Li, S.; Chung, S.H.; Zhu, L.; Stayt, J.; Su, T.; Couraud, P.-O.; Romero, I.A.; Weksler, B.; Gillies, M.C. Tyrosine phosphorylation of VE-cadherin and claudin- 5 is associated with TGF- $\beta 1$-induced permeability of centrally derived vascular endothelium. Eur. J. Cell Boil. 2011, 90, 323-332. [CrossRef]

81. Li, F.; Lan, Y.; Wang, Y.; Wang, J.; Yang, G.; Meng, F.; Han, H.; Meng, A.; Wang, Y.; Yang, X. Endothelial Smad4 maintains cerebrovascular integrity by activating $\mathrm{N}$-cadherin through cooperation with Notch. Dev. Cell 2011, 20, 291-302. [CrossRef]

82. Acosta, S.A.; Tajiri, N.; de la Pena, I.; Bastawrous, M.; Sanberg, P.R.; Kaneko, Y.; Borlongan, C.V. Alpha-synuclein as a pathological link between chronic traumatic brain injury and Parkinson's disease. J. Cell. Physiol. 2015, 230, 1024-1032. [CrossRef] [PubMed]

83. Hernandez-Ontiveros, D.G.; Tajiri, N.; Acosta, S.; Giunta, B.; Tan, J.; Borlongan, C.V. Microglia activation as a biomarker for traumatic brain injury. Front. Neurol. 2013, 4, 30. [CrossRef] [PubMed]

84. Acosta, S.A.; Tajiri, N.; Shinozuka, K.; Ishikawa, H.; Grimmig, B.; Diamond, D.; Sanberg, P.R.; Bickford, P.C.; Kaneko, Y.; Borlongan, C.V. Long-term upregulation of inflammation and suppression of cell proliferation in the brain of adult rats exposed to traumatic brain injury using the controlled cortical impact model. PLoS ONE 2013, 8, e53376. [CrossRef]

85. Fluiter, K.; Opperhuizen, A.L.; Morgan, B.P.; Baas, F.; Ramaglia, V. Inhibition of the membrane attack complex of the complement system reduces secondary neuroaxonal loss and promotes neurologic recovery after traumatic brain injury in mice. J. Immunol. 2014, 192, 2339-2348. [CrossRef] [PubMed]

86. Xiong, Y.; Mahmood, A.; Chopp, M. Current understanding of neuroinflammation after traumatic brain injury and cell-based therapeutic opportunities. Chin. J. Traumatol. 2018, 21, 137-151. [CrossRef]

87. Thau-Zuchman, O.; Shohami, E.; Alexandrovich, A.; Leker, R. Subacute treatment with vascular endothelial growth factor after traumatic brain injury increases angiogenesis and gliogenesis. Neuroscience 2012, 202, 334-341. [CrossRef]

88. Weston, N.M.; Sun, D. The Potential of stem cells in treatment of traumatic brain injury. Curr. Neurol. Neurosci. Rep. 2018, 18, 1. [CrossRef]

89. Sun, D. The potential of endogenous neurogenesis for brain repair and regeneration following traumatic brain injury. Neural Regen. Res. 2014, 9, 688-692. [CrossRef]

90. Sun, D.; McGinn, M.; Hankins, J.E.; Mays, K.M.; Rolfe, A.; Colello, R.J. Aging- and injury-related differential apoptotic response in the dentate gyrus of the hippocampus in rats following brain trauma. Front. Aging Neurosci. 2013, 5, 95. [CrossRef]

91. Xu, H.-M. Th1 cytokine-based immunotherapy for cancer. Hepatobiliary Pancreat. Dis. Int. 2014, 13, $482-494$. [CrossRef]

92. Ye, L.; Huang, Y.; Zhao, L.; Li, Y.; Sun, L.; Zhou, Y.; Qian, G.; Zheng, J. IL-1 $\beta$ and TNF- $\alpha$ induce neurotoxicity through glutamate production: A potential role for neuronal glutaminase. J. Neurochem. 2013, 125, 897-908. [CrossRef] [PubMed]

93. Baker, R.G.; Hayden, M.; Ghosh, S. NF-кB, Inflammation, and metabolic disease. Cell Metab. 2011, 13, 11-22. [CrossRef] [PubMed]

94. Hayden, M.; Ghosh, S. NF- $\mathrm{B}$, the first quarter-century: Remarkable progress and outstanding questions. Genes Dev. 2012, 26, 203-234. [CrossRef] [PubMed] 
95. Zhang, Q.; Lenardo, M.J.; Baltimore, D. 30 years of NF-kB: A blossoming of relevance to human pathobiology. Cell 2017, 168, 37-57. [CrossRef]

96. Mettang, M.; Reichel, S.N.; Lattke, M.; Palmer, A.; Abaei, A.; Rasche, V.; Huber-Lang, M.; Baumann, B.; Wirth, T. IKK2/NF-KB signaling protects neurons after traumatic brain injury. FASEB J. 2018, 32, 1916-1932. [CrossRef]

97. Badaut, J.; Ashwal, S.; Obenaus, A. Aquaporins in cerebrovascular disease: A target for treatment of brain edema? Cerebrovasc. Dis. 2011, 31, 521-531. [CrossRef]

98. Xu, J.; Wang, H.; Ding, K.; Zhang, L.; Wang, C.; Li, T.; Wei, W.; Lu, X. Luteolin provides neuroprotection in models of traumatic brain injury via the Nrf2-ARE pathway. Free. Radic. Boil. Med. 2014, 71, 186-195. [CrossRef]

99. Mutinati, M.; Pantaleo, M.; Roncetti, M.; Piccinno, M.; Rizzo, A.; Sciorsci, R. Oxidative stress in neonatology. A review. Reprod. Domest. Anim. 2013, 49,7-16. [CrossRef]

100. Wang, J.; Wang, H.; Cong, Z.-X.; Zhou, X.-M.; Xu, J.-G.; Jia, Y.; Ding, Y. Puerarin ameliorates oxidative stress in a rodent model of traumatic brain injury. J. Surg. Res. 2014, 186, 328-337. [CrossRef]

101. Arent, A.M.; De Souza, L.; Walz, R.; Dafre, A.L. Perspectives on molecular biomarkers of oxidative stress and antioxidant strategies in traumatic brain injury. BioMed Res. Int. 2014, 2014, 1-18. [CrossRef]

102. Rodríguez-Rodríguez, A.; Egea-Guerrero, J.J.; Murillo-Cabezas, F.; Carrillo-Vico, A. Oxidative stress in traumatic brain injury. Curr. Med. Chem. 2014, 21, 1201-1211. [CrossRef] [PubMed]

103. Ferreira, A.P.O.; Rodrigues, F.; Della-Pace, I.D.; Mota, B.C.; Oliveira, S.M.; Gewehr, C.D.C.V.; Bobinski, F.; De Oliveira, C.V.; Brum, J.S.; Oliveira, M.S.; et al. The effect of NADPH-oxidase inhibitor apocynin on cognitive impairment induced by moderate lateral fluid percussion injury: Role of inflammatory and oxidative brain damage. Neurochem. Int. 2013, 63, 583-593. [CrossRef] [PubMed]

104. Kumar, A.; Álvarez-Croda, D.-M.; Stoica, B.A.; Faden, A.I.; Loane, D.J. Microglial/macrophage polarization dynamics following traumatic brain injury. J. Neurotrauma 2016, 33, 1732-1750. [CrossRef] [PubMed]

105. He, Y.; Yan, H.; Ni, H.; Liang, W.; Jin, W. Expression of nuclear factor erythroid 2-related factor 2 following traumatic brain injury in the human brain. NeuroReport 2019, 30, 344-349. [CrossRef] [PubMed]

106. Zhou, Y.; Tian, M.; Wang, H.; Gao, C.-C.; Zhu, L.; Lin, Y.-X.; Fang, J.; Ding, K. Activation of the Nrf2-ARE signal pathway after blast induced traumatic brain injury in mice. Int. J. Neurosci. 2019, 1-7. [CrossRef]

107. Lu, X.-Y.; Wang, H.; Xu, J.-G.; Ding, K.; Li, T. Deletion of Nrf2 exacerbates oxidative stress after traumatic brain injury in mice. Cell. Mol. Neurobiol. 2015, 35, 713-721. [CrossRef]

108. Stocchetti, N.; Zanier, E.R. Chronic impact of traumatic brain injury on outcome and quality of life: A narrative review. Crit. Care 2016, 20, 148. [CrossRef]

109. Xiong, Y.; Mahmood, A.; Chopp, M. Emerging treatments for traumatic brain injury. Expert Opin. Emerg. Drugs 2009, 14, 67-84. [CrossRef]

110. Langham, J.; Goldfrad, C.; Teasdale, G.; Shaw, D.; Rowan, K. Calcium channel blockers for acute traumatic brain injury. Cochrane Database Syst. Rev. 2003, 2003, CD000565. [CrossRef]

111. Berman, R.F.; Verweij, B.H.; Muizelaar, J.P. Neurobehavioral protection by the neuronal calcium channel blocker Ziconotide in a model of traumatic diffuse brain injury in rats. J. Neurosurg. 2000, 93, 821-828. [CrossRef]

112. Verweij, B.H.; Muizelaar, J.P.; Vinas, F.C.; Peterson, P.L.; Xiong, Y.; Lee, C.P. Improvement in mitochondrial dysfunction as a new surrogate efficiency measure for preclinical trials: Dose-Response and time-window profiles for administration of the calcium channel blocker Ziconotide in experimental brain injury. J. Neurosurg. 2000, 93, 829-834. [CrossRef] [PubMed]

113. Sorani, M.D.; Morabito, D.; Rosenthal, G.; Giacomini, K.M.; Manley, G.T. Characterizing the dose-response relationship between mannitol and intracranial pressure in traumatic brain injury patients using a high-frequency physiological data collection system. J. Neurotrauma 2008, 25, 291-298. [CrossRef] [PubMed]

114. Roberts, I.; Schierhout, G. Mannitol for acute traumatic brain injury. Cochrane Database Syst. Rev. 2005, CD001049. [CrossRef]

115. Giacino, J.T.; Whyte, J.; Bagiella, E.; Kalmar, K.; Childs, N.; Khademi, A.; Eifert, B.; Long, D.; Katz, D.; Cho, S.; et al. Placebo-controlled trial of amantadine for severe traumatic brain injury. New Engl. J. Med. 2012, 366, 819-826. [CrossRef] [PubMed]

116. Sawyer, E.; Maura, L.S.; Ohlinger, M.J. Amantadine enhancement of arousal and cognition after traumatic brain injury. Ann. Pharmacother. 2008, 42, 247-252. [CrossRef] [PubMed] 
117. Werner, C.; Engelhard, K. Pathophysiology of traumatic brain injury. Br. J. Anaesth. 2007, 99, 4-9. [CrossRef]

118. Wu, G.; Liu, Z. Nuclear factor erythroid 2-related factor 2 (Nrf2) mediates neuroprotection in traumatic brain injury at least in part by inactivating microglia. Med. Sci. Monit. 2016, 22, 2161-2166. [CrossRef]

119. Kakkar, V.; Kaur, I.P. Evaluating potential of curcumin loaded solid lipid nanoparticles in aluminium induced behavioural, biochemical and histopathological alterations in mice brain. Food Chem. Toxicol. 2011, 49, 2906-2913. [CrossRef]

120. Agarwal, N.B.; Jain, S.; Agarwal, N.K.; Mediratta, P.K.; Sharma, K.K. Modulation of pentylenetetrazole-induced kindling and oxidative stress by curcumin in mice. Phytomedicine 2011, 18, 756-759. [CrossRef]

121. Carmona-Ramírez, I.; Santamaría, A.; Tobon-Velasco, J.C.; Orozco-Ibarra, M.; Gonzalez-Herrera, I.G.; Pedraza-Chaverri, J.; Maldonado, P.D. RETRACTED: Curcumin restores Nrf2 levels and prevents quinolinic acid-induced neurotoxicity. J. Nutr. Biochem. 2013, 24, 14-24. [CrossRef]

122. Huang, Y.; Li, W.; Su, Z.-Y.; Kong, A.-N. The complexity of the Nrf2 pathway: Beyond the antioxidant response. J. Nutr. Biochem. 2015, 26, 1401-1413. [CrossRef] [PubMed]

123. Scapagnini, G.; Vasto, S.; Sonya, V.; Abraham, N.G.; Nader, A.G.; Caruso, C.; Calogero, C.; Zella, D.; Fabio, G. Modulation of Nrf2/ARE pathway by food polyphenols: A nutritional neuroprotective strategy for cognitive and neurodegenerative disorders. Mol. Neurobiol. 2011, 44, 192-201. [CrossRef] [PubMed]

124. De Alcântara, G.F.T.; Simões-Neto, E.; Da Cruz, G.M.P.; Nobre, M.E.P.; Neves, K.; Andrade, G.; Brito, G.A.D.C.; Viana, G.S.D.B. Curcumin reverses neurochemical, histological and immuno-histochemical alterations in the model of global brain ischemia. J. Tradit. Complement. Med. 2016, 7, 14-23. [CrossRef] [PubMed]

125. Maiti, P.; Hall, T.C.; Paladugu, L.; Kolli, N.; Learman, C.; Rossignol, J.; Dunbar, G.L. A comparative study of dietary curcumin, nanocurcumin, and other classical amyloid-binding dyes for labeling and imaging of amyloid plaques in brain tissue of 5×-familial Alzheimer's disease mice. Histochem. Cell Biol. 2016, 146, 609-625. [CrossRef]

126. Wang, B.-F.; Cui, Z.-W.; Zhong, Z.-H.; Sun, Y.-H.; Sun, Q.-F.; Yang, G.-Y.; Bian, L.-G. Curcumin attenuates brain edema in mice with intracerebral hemorrhage through inhibition of AQP4 and AQP9 expression. Acta Pharmacol. Sin. 2015, 36, 939-948. [CrossRef]

127. Li, W.; Suwanwela, N.C.; Patumraj, S. Curcumin by down-regulating NF-kB and elevating Nrf2, reduces brain edema and neurological dysfunction after cerebral I/R. Microvasc. Res. 2016, 106, 117-127. [CrossRef]

128. Tu, Z.-S.; Wang, Q.; Sun, D.-D.; Dai, F.; Zhou, B. Design, synthesis, and evaluation of curcumin derivatives as Nrf2 activators and cytoprotectors against oxidative death. Eur. J. Med. Chem. 2017, 134, 72-85. [CrossRef]

129. Wu, A.; Ying, Z.; Schubert, D.; Gomez-Pinilla, F. Brain and spinal cord interaction. Neurorehabilit. Neural Repair 2011, 25, 332-342. [CrossRef]

130. Zhu, H.-T.; Bian, C.; Yuan, J.-C.; Chu, W.-H.; Xiang, X.; Chen, F.; Wang, C.-S.; Feng, H.; Lin, J.-K. Curcumin attenuates acute inflammatory injury by inhibiting the TLR4/MyD88/NF- $\mathrm{BB}$ signaling pathway in experimental traumatic brain injury. J. Neuroinflamm. 2014, 11, 59. [CrossRef]

131. Alfieri, A.; Srivastava, S.; Siow, R.C.; Cash, D.; Modo, M.; Duchen, M.R.; Fraser, P.A.; Williams, S.C.; Mann, G.E. Sulforaphane preconditioning of the Nrf2/HO-1 defense pathway protects the cerebral vasculature against blood-brain barrier disruption and neurological deficits in stroke. Free Radic. Biol. Med. 2013, 65, 1012-1022. [CrossRef]

132. Tarozzi, A.; Angeloni, C.; Malaguti, M.; Morroni, F.; Hrelia, S.; Hrelia, P. Sulforaphane as a potential protective phytochemical against neurodegenerative diseases. Oxidative Med. Cell. Longev. 2013, 2013, 1-10. [CrossRef] [PubMed]

133. Mao, L.; Yang, T.; Li, X.; Lei, X.; Sun, Y.; Zhao, Y.; Zhang, W.; Gao, Y.; Sun, B.; Zhang, F. Protective effects of sulforaphane in experimental vascular cognitive impairment: Contribution of the Nrf2 pathway. Br. J. Pharmacol. 2018, 39, 352-366. [CrossRef] [PubMed]

134. Soane, L.; Dai, W.L.; Fiskum, G.; Bambrick, L.L. Sulforaphane protects immature hippocampal neurons against death caused by exposure to hemin or to oxygen and glucose deprivation. J. Neurosci. Res. 2010, 88, 1355-1363. [CrossRef] [PubMed]

135. Yu, C.; He, Q.; Zheng, J.; Li, L.Y.; Hou, Y.H.; Song, F.Z. Sulforaphane improves outcomes and slows cerebral ischemic/reperfusion injury via inhibition of NLRP3 inflammasome activation in rats. Int. Immunopharmacol. 2017, 45, 74-78. [CrossRef] [PubMed] 
136. Holloway, P.M.; Gillespie, S.; Becker, F.; Vital, S.A.; Nguyen, V.; Alexander, J.S.; Evans, P.C.; Gavins, F.N. Sulforaphane induces neurovascular protection against a systemic inflammatory challenge via both Nrf2-dependent and independent pathways. Vasc. Pharmacol. 2016, 85, 29-38. [CrossRef] [PubMed]

137. Dinkova-Kostova, A.T.; Dinkova-Kostova, A.T. Glucosinolates and isothiocyanates in health and disease. Trends Mol. Med. 2012, 18, 337-347. [CrossRef]

138. Zhao, X.; Wen, L.; Dong, M.; Lu, X. Sulforaphane activates the cerebral vascular Nrf2-ARE pathway and suppresses inflammation to attenuate cerebral vasospasm in rat with subarachnoid hemorrhage. Brain Res. 2016, 1653, 1-7. [CrossRef]

139. Takaya, K.; Suzuki, T.; Motohashi, H.; Onodera, K.; Satomi, S.; Kensler, T.W.; Yamamoto, M. Validation of the multiple sensor mechanism of the Keap1-Nrf2 system. Free. Radic. Boil. Med. 2012, 53, 817-827. [CrossRef]

140. Moon, D.-O.; Kim, M.-O.; Kang, S.-H.; Choi, Y.H.; Kim, G.-Y. Sulforaphane suppresses TNF- $\alpha$-mediated activation of NF- $\mathrm{kB}$ and induces apoptosis through activation of reactive oxygen species-dependent caspase-3. Cancer Lett. 2009, 274, 132-142. [CrossRef]

141. Checker, R.; Gambhir, L.; Thoh, M.; Sharma, D.; Sandur, S.K. Sulforaphane, a naturally occurring isothiocyanate, exhibits anti-inflammatory effects by targeting GSK3 $\beta / \mathrm{Nrf}-2$ and NF- $\mathrm{B}$ pathways in T cells. J. Funct. Foods 2015, 19, 426-438. [CrossRef]

142. Ashabi, G.; Khalaj, L.; Khodagholi, F.; Goudarzvand, M.; Sarkaki, A. Pre-treatment with metformin activates $\mathrm{Nrf} 2$ antioxidant pathways and inhibits inflammatory responses through induction of AMPK after transient global cerebral ischemia. Metab. Brain Dis. 2014, 30, 747-754. [CrossRef] [PubMed]

143. Liu, Y.; Tang, G.; Li, Y.; Wang, Y.; Chen, X.; Gu, X.; Zhang, Z.; Wang, Y.; Yang, G.-Y. Metformin attenuates blood-brain barrier disruption in mice following middle cerebral artery occlusion. J. Neuroinflamm. 2014, 11, 177. [CrossRef] [PubMed]

144. Prasad, S.; Sajja, R.K.; Kaisar, M.A.; Park, J.H.; Villalba, H.; Liles, T.; Abbruscato, T.J.; Cucullo, L. Role of $\mathrm{Nrf} 2$ and protective effects of Metformin against tobacco smoke-induced cerebrovascular toxicity. Redox Boil. 2017, 12, 58-69. [CrossRef] [PubMed]

145. Isoda, K.; Young, J.L.; Zirlik, A.; Macfarlane, L.A.; Tsuboi, N.; Gerdes, N.; Schönbeck, U.; Libby, P. Metformin Inhibits Proinflammatory Responses and Nuclear Factor-кB in Human Vascular Wall Cells. Arter. Thromb. Vasc. Boil. 2006, 26, 611-617. [CrossRef]

146. Hattori, Y.; Suzuki, K.; Hattori, S.; Kasai, K. Metformin Inhibits Cytokine-Induced Nuclear Factor кB Activation Via AMP-Activated Protein Kinase Activation in Vascular Endothelial Cells. Hypertension 2006, 47, 1183-1188. [CrossRef]

147. Li, S.N.; Wang, X.; Zeng, Q.T.; Feng, Y.B.; Cheng, X.; Mao, X.B.; Wang, T.H.; Deng, H.P. Metformin inhibits nuclear factor kappaB activation and decreases serum high-sensitivity $C$-reactive protein level in experimental atherogenesis of rabbits. Heart Vessels 2009, 24, 446-453. [CrossRef]

148. Kim, H.G.; Hien, T.T.; Han, E.H.; Hwang, Y.P.; Choi, J.H.; Kang, K.W.; Kwon, K.I.; Kim, B.H.; Kim, S.K.; Song, G.Y.; et al. Metformin inhibits P-glycoprotein expression via the NF-kappaB pathway and CRE transcriptional activity through AMPK activation. Br. J. Pharmacol. 2011, 162, 1096-1108. [CrossRef]

149. Kaisar, M.A.; Villalba, H.; Prasad, S.; Liles, T.; Sifat, A.E.; Sajja, R.K.; Abbruscato, T.J.; Cucullo, L. Offsetting the impact of smoking and e-cigarette vaping on the cerebrovascular system and stroke injury: Is Metformin a viable countermeasure? Redox Boil. 2017, 13, 353-362. [CrossRef]

150. Pryor, R.; Cabreiro, F. Repurposing metformin: An old drug with new tricks in its binding pockets. Biochem. J. 2015, 471, 307-322. [CrossRef]

151. Jin, Q.; Cheng, J.; Liu, Y.; Wu, J.; Wang, X.; Wei, S.; Zhou, X.; Qin, Z.; Jia, J.; Zhen, X.-C. Improvement of functional recovery by chronic metformin treatment is associated with enhanced alternative activation of microglia/macrophages and increased angiogenesis and neurogenesis following experimental stroke. Brain Behav. Immun. 2014, 40, 131-142. [CrossRef]

152. Ou, Z.; Kong, X.; Sun, X.; He, X.; Zhang, L.; Gong, Z.; Huang, J.; Xu, B.; Long, D.; Li, J.; et al. Metformin treatment prevents amyloid plaque deposition and memory impairment in APP/PS1 mice. Brain Behav. Immun. 2018, 69, 351-363. [CrossRef] [PubMed]

153. Tanokashira, D.; Kurata, E.; Fukuokaya, W.; Kawabe, K.; Kashiwada, M.; Takeuchi, H.; Nakazato, M.; Taguchi, A. Metformin treatment ameliorates diabetes-associated decline in hippocampal neurogenesis and memory via phosphorylation of insulin receptor substrate 1. FEBS Open Bio 2018, 8, 1104-1118. [CrossRef] [PubMed] 
154. Wang, J.; Jiang, C.; Zhang, K.; Lan, X.; Chen, X.; Zang, W.; Wang, Z.; Guan, F.; Zhu, C.; Yang, X.; et al. Melatonin receptor activation provides cerebral protection after traumatic brain injury by mitigating oxidative stress and inflammation via the Nrf2 signaling pathway. Free Radic. Boil. Med. 2019, 131, 345-355. [CrossRef] [PubMed]

155. Lequerica, A.; Jasey, N.; Tremont, J.N.P.; Chiaravalloti, N.D. Pilot study on the effect of ramelteon on sleep disturbance after traumatic brain injury: Preliminary evidence from a clinical trial. Arch. Phys. Med. Rehabilitation 2015, 96, 1802-1809. [CrossRef] [PubMed]

156. Bergold, P. Treatment of traumatic brain injury with anti-inflammatory drugs. Exp. Neurol. 2015, 275, 367-380. [CrossRef]

(C) 2020 by the authors. Licensee MDPI, Basel, Switzerland. This article is an open access article distributed under the terms and conditions of the Creative Commons Attribution (CC BY) license (http://creativecommons.org/licenses/by/4.0/). 